\title{
Measures on Electric Vehicles Charging Piles Based on Beijing haze
}

\author{
Yurong Zeng \\ School of Economic and Management, North China Electric Power University, Beijing, 102206 China \\ hdddqccdz@163.com
}

Keywords: haze, electric vehicle, correlation coefficient analysis, environmental impact, electric vehicles charging piles.

\begin{abstract}
At present, the increasingly heavy pollution haze in Beijing has widely been paid attention. According to index of pm2.5 data for the past few years, correlation coefficients of simple coefficient among different characters are analyzed. The result is that there are three main reasons giving rise to the pollution haze, including surrounding provinces pollution transmission, urban tailpipe emission, coal using and local heavy industry. However, through feasibility analysis, there are the enormous difficulties to completing industry transition for surrounding provinces in short order. And it is also infeasible to eliminate the negative influence of severe weather. It is a challenge for Beijing to clean the atmosphere without choking off growth. There is an urgent need to improve air quality for Beijing, the capital of China. Based on that situation, there are no simple solutions to pollution haze, but people could reduce it by saving energy and reducing the emissions from vehicle exhausts. The electric vehicle charging piles can contribute a great to energy conservation and carbon emission reduction, which can relieve the pollution haze in Beijing. In that case, the promotion of large-scale electric vehicle charging piles is a significant solution for reducing fossil energy consumption and coping with environmental pollution, which will also bring sustainable economic development for Beijing. It is of strategic significance for government to promote electric vehicle charging piles in Beijing.
\end{abstract}

\section{Zone transfer}

Beijing is surrounded by heavy industrial cities. When the temperature drops, the surrounding urban air pollution particles of dust can go into Beijing areas by hot and cold air convection. However, it is difficult to spread out by the limitations of the Gulf topography, leading to air pollution of the atmosphere and a chemical reaction of the atmosphere, forming a haze. The haze fog in Hebei and Tianjin province will also lead to Beijing haze.

As is can be seen in Beijing Environment Bulletin in 2014, the one-third zone transfers brought about $34 \%$ of the total accounted for the haze. According to the Fig.3-2 and Fig.3-3, despite related pollutant emissions in Beijing remain stable, the sulfur dioxide emissions from the neighboring provinces of Beijing, industrial emissions overall present an upward trend, maintaining a high level. From the seasonal change point of view, in summer, the contribution in the outside field is small, while in winter it makes a great contribution. Regionally, the concentration of sulfur dioxide in Baoding, Tianjin, Langfang, Tangshan, Zhangjiakou and Beijing and other regions contribute more. The surrounding areas of Beijing, it is still coal-dominated energy structure, especially in Hebei, the province's total energy consumption in 2012 was 3.02 million tonnes of coal, of which coal consumption accounted for about $90 \%$, higher than the national 20 percentage points. Tianjin and Hebei province also gather a lot of cement, steel, oil refining and petrochemical high-polluting industries. The total areas are full of more than 350 million tons of coal-fired, high emissions intensity per unit area and atmospheric environment issues. The character of PM2.5 is that it is long in the air and the floating distance is large. So, if Beijing does not change the conditions of the surrounding areas, it is really difficult to change the overall air quality environment in Beijing city. 


\section{Local sources}

Form the human factor of the formation of the haze, the current air pollution is not a simple automobile exhaust pollution. In the past 10 years, the particulate emissions of North China once decreased and there were no significant increases in the total amount of PM2.5, but fog and haze have significantly increased. Laboratory simulation and field observations indicate that the "under atmospheric conditions combined pollution between pollutants react with each other, resulting in enhanced atmospheric oxidation and accelerating the transformation of gas particles. Therefore, the Chinese air pollution is facing old and new health problems concentrated outbreak, which belongs to the unique complex types of pollution.

The study found that Beijing has six important sources of PM2.5, which are inorganic aerosols (refers to a chemical reaction can cause air pollution sulfides and nitrides occurs in the atmosphere), industrial pollution, coal, soil dust, biomass burning, vehicle exhaust and waste incineration, which account for $26 \%, 25 \%, 18 \%, 15 \%, 12 \%$ and $4 \%$ respectively. The secondary inorganic aerosols, industrial pollution and coal-fired combined fossil with fuel combustion emissions have become major sources of PM2.5 pollution in Beijing.

\subsection{Industrial and coal-fired heating}

Urbanization relies on the development of industrialization, with cannot be without fuel, especially in power generation, steel, chemical and other industries. PM2.5 is fired due to three main aspects, one coal combustion flue gas is formed of fine particulate matter and the flue gas SOx, NOx formed by the photochemical action. The coal VOCs itself also contains incomplete combustion into the air. By comparing the calculated correlation coefficients among the indexes, we can see that the use of coal and sulfur dioxide daily average (mg / m3), sulfur dioxide (SO2) emissions (tonnes) showed a strong correlation relationship and it is also on daily average of the respirable particulate matter ( $\mathrm{mg} / \mathrm{m} 3)$. This shows the use of coal can really bring sulfur dioxide, which leads to the generation of fog and haze.

Table 3-1 Beijing coal use and related indicators of the underlying index

\begin{tabular}{|c|c|c|c|}
\hline $\begin{array}{c}\text { correlation } \\
\text { coefficient }\end{array}$ & $\begin{array}{c}\text { average daily respirable } \\
\text { particulate value }\end{array}$ & $\begin{array}{c}\text { average daily sulfur } \\
\text { dioxide value }\end{array}$ & $\begin{array}{c}\text { Sulfur dioxide (SO2) } \\
\text { emissions }\end{array}$ \\
\hline $\begin{array}{c}\text { Coal usage } \\
\text { (tonnes) }\end{array}$ & 0.66 & 0.96 & 0.98 \\
\hline
\end{tabular}

\subsection{Motor vehicle and related industries}

The present situation in Beijing is that in 2014, the city's vehicle population was 5.371 million, the annual discharge of pollutants was 90 million tons. The main pollutant in vehicle emissions contribution rate is relatively high, which shares $86 \%$ of carbon monoxide, $57 \%$ of nitrogen oxides, $38 \%$ share of hydrocarbons and $20-50 \%$ of the PM2.5 contribution. The number of motor vehicle emissions of pollutants is 5-10 times the rate of growth. Studies have confirmed that a large number of motor vehicle emissions of nitrogen oxides promote the conversion of sulfur dioxide emissions from coal burning of the PM2.5. Automobile exhaust contains a lot of calories and nitrogen oxides, through direct sunlight, eventually forming into chemical smog called haze which is an important component substance. By comparing the Beijing 2008 - Car of the total in 2014 and related factors correlation coefficient, the total number of vehicles can be found in heavily polluted by the proportion of time a strong correlation. Description of vehicle does significantly affect atmospheric conditions and nitrogen dioxide, mainly through the influence of air.

Table 3-2 The relevant indicators of correlation coefficient and total vehicle population

\begin{tabular}{|c|c|c|c|c|}
\hline $\begin{array}{c}\text { correlation } \\
\text { coefficient }\end{array}$ & $\begin{array}{c}\text { Serious pollution of } \\
\text { proportion time ( } \\
250)\end{array}$ & $\begin{array}{c}\text { Nitrogen dioxide } \\
\text { daily average (mg / } \\
\text { m3) }\end{array}$ & $\begin{array}{c}\text { Sulfur dioxide } \\
\text { (SO2) emissions } \\
\text { (tons) }\end{array}$ & $\begin{array}{c}\text { Dust } \\
\text { emissions } \\
\text { (tons) }\end{array}$ \\
\hline Total car & 0.88 & 0.75 & 0.55 & 0.51 \\
\hline
\end{tabular}




\subsection{Heavy pollution}

China now has the world's largest and complete industrial system. Industry not only provides raw materials and products for the economy and society, but also consumes a lot of resources and energy emissions of pollutants. Industrial production is an important source of air pollution. Low levels of dust control in the industrial sector and electric, steel and coal industry, mineral products and other annual dust emissions accounted for nearly $70 \%$ of national emissions. By comparing the Beijing 2008 and the related coefficient 2014 heavy industry, related factors can be found in heavy industry and heavily polluted by the proportion of time a strong correlation, while nitrogen dioxide and chemical oxygen demand emissions also have a strong correlation.

Table 3-3 The correlation coefficient Beijing heavy industry and related indicators

\begin{tabular}{|c|c|c|c|}
\hline $\begin{array}{c}\text { Correlation } \\
\text { coefficient }\end{array}$ & $\begin{array}{c}\text { Serious pollution of the } \\
\text { proportion of time (> 250) }\end{array}$ & $\begin{array}{c}\text { Average Nitrogen } \\
\text { dioxide daily (mg / m3) }\end{array}$ & $\begin{array}{c}\text { COD emissions } \\
\text { (tonnes) }\end{array}$ \\
\hline $\begin{array}{c}\text { Heavy industry } \\
\text { value (million) }\end{array}$ & 0.82 & 0.70 & 0.73 \\
\hline
\end{tabular}

\subsection{Dust}

Dust's component is PM10, which refers to an important component of the environment. The long-term floating particulate matter is dust. Dust pollution refers to housing construction, roads and pipelines, municipal utilities, port construction, building construction, building, structure demolition, quarrying earth, material handling and stacking, cleaning public places and roads and other conservation activities. In the wind, the speed is low, so a large number of dusts cannot be timely float in the air and water vapor diffusion mixing after the formation of haze. Accordingly, the generation of dust haze weather is the main reason. Industry forms the main particulate matter in two ways: Firstly, ultrafine particulate matter emissions from various industrial processes directly; secondly, ultrafine particles formed in the atmosphere and the like secondary aerosols. Among them, the first approach is the main source of the formation of particulate matter. As we can see from the following table, industrial dust emissions and pm2.5 serious pollution proportion of time $(>250)$ have moderate correlations.

Table 3-4 The coefficient correlation of industrial dust emissions and related indicators

\begin{tabular}{|c|c|c|}
\hline & PM2.5 average value & $\begin{array}{c}\text { Serious pollution of the proportion of } \\
\text { time (> 250) }\end{array}$ \\
\hline $\begin{array}{c}\text { Industrial dust emissions } \\
\text { (tons) }\end{array}$ & 0.48 & 0.49 \\
\hline
\end{tabular}

\section{Conclusions to haze Causes}

Through the analysis of the above, there are three main reasons of haze in Beijing:

1) Because of the economic development and increased population, Beijing has a large demand in coal-burning and motor vehicles, leading to more native pollutants.

2) Hebei, Tianjin areas around Beijing have developed heavy industries, producing much pollutant to Beijing.

3) It has adverse impacts for pollution because of Beijing mountainous terrain and continuous bad weather conditions.

\section{Conclusion and Prospect}

Through the above analysis, the role of natural factors occurred despite the haze in Beijing, but the sources of pollution are caused by human factors. In the haze is particularly acute at the beginning of 2016, Beijing came odd and even number lines may normalization news aroused public opposition. The low emission characteristics of an electric car can be a good solution to the problem of urban haze. Despite the risk of haze passed on generation side, but with the rapid development of the 
surrounding areas of Beijing, Hebei, Inner Mongolia clean energy wind power, electric cars still have great potential to alleviate haze. And the charging of electric vehicles is focused on low power at night, with a good "load shifting" effect, which is in favor of comprehensive utilization of resources and reduce emissions, thus easing the haze in Beijing. In summary, extensive promotion of electric vehicles, to ease the haze in Beijing really helpful and has great potential.

Counter measures based on promotion of electric vehicles:

1) In accordance with the characteristics of the electric vehicle energy types, their respective merits vary. We should widely promote pure electric vehicles, hybrid electric vehicles and fuel cell electric vehicles. We should promote electric vehicles in public transportation, logistics and other industries and promote hybrid electric vehicles in private vehicles. Finally, in terms of large-scale remote trucks, we are supposed to use fuel cell electric vehicles.

2) The Government promote achieve vehicle charging pile manufacturing and accounting standardization. In Beijing, the electric vehicle charging piles are hard to do as the US and Europe who use the home garage charging, the main method of charging electric vehicle is still public charging pile. Unified charging and billing pile charging standard electric car can solve the user's worries, helping to promote the widespread use of electric vehicles.

3) Beijing surrounding areas are to develop wind power and other clean energy. Around Beijing, Inner Mongolia, Hebei and other regions have abundant wind energy resources. They should be able to reduce the proportion of thermal power generation and improve the proportion of clean energy. Large-scale promotion of electric vehicles can reduce emissions in greater extent.

4) In order to guide users of electric vehicles power load peak hours charged, low hours in idle power is to be used. The study found that long-term future of electric vehicles and large-scale development is also closely related to use charging period. The peak power system accounts for $73 \%$ of the average, nighttime surplus electricity can be solved in more than $90 \%$ of electric vehicle charging needs. The car battery electric vehicle two want Rise mains power supply (VEHICLE TO GRID) to power homes and electric vehicles (VECHICLE TO HOME) technology. They also greatly improve the utilization of electricity.

\section{References}

[1] Yingdeng Peng, "analysis of the causes and control of Beijing haze pollution recently", "Engineering Research", Vol. 5, No. 3.

[2] Beijing Environmental Protection Bureau, "Beijing 2014 State of the Environment".

[3] Daihe Jiang, "illustration of " haze "and PM2.5", "Modern Physics", Vol. 26 No. 2.

[4] Yuesi Wang, "Where does haze come from", "World of Science" 20144

[5] Xiaoqing Shi, Xiaonuo Li, Jianxin Yang, "Analysis of low-carbon transportation electric vehicle carbon emission reduction potential and its influencing factors". 